\title{
Financial Management System, Legislation and Stakeholders
}

\author{
Nils Soguel
}

\subsection{INTRODUCTION}

This chapter briefly depicts how financial management at the various Swiss government levels is governed by legislation and organized in practice. It presents the legal framework, the main institutional settings and the actors involved ${ }^{1}$. Within the Swiss federalist system, the cantons exercise considerable autonomy in financial management; each canton has designed its own way to manage its public finances. The 'standard'

\footnotetext{
${ }^{1}$ Here we use 'government' in the way it is used by the International Monetary Fund (IMF 2014): a unique legal entity established by political processes that has legislative, judicial or executive authority over other institutional units (households, corporations and non-profit institutions) within a given area (p. 14). Therefore, a government is an organization that includes several branches: a legislature (parliament), an executive branch with its administration and a judiciary, either at the federal, the cantonal or the municipal level.
}

The author is grateful to Aurélia Buchs and Ramon Christen for their contribution to this chapter.

N. Soguel $(\bowtie)$

IDHEAP, University of Lausanne, Lausanne, Switzerland e-mail: nils.soguel@unil.ch

(C) The Author(s) 2019

A. Ladner et al. (eds.), Swiss Public Administration, Governance and Public Management, https://doi.org/10.1007/978-3-319-92381-9_14 
financial management both at the level of the Confederation (the upper tier) and at the cantonal level is summarized here, and while their financial system is similar, municipalities are not explicitly addressed.

The following section presents the legal foundations and guiding principles of financial management at the national and cantonal levels. Section 14.3 addresses the implications the legal foundations have for preparing and implementing the budget, detailing the role the different bodies play at each stage of the process. Section 14.4 is dedicated to two specifically Swiss institutions meant to ensure the government's fiscal sustainability, the fiscal rules $^{2}$ and the financial referendum together with the right of initiative.

\subsection{LEgal Foundations}

The legal foundation governing financial management is provided by the Constitution and the Financial Management Act of Parliament (FMAP). The same legal architecture prevails at the level of the Confederation and in each of the 26 cantons. Each canton is free to decide upon the procedures for managing its budget. Therefore, each canton also has its own FMAP. Cantonal FMAPs have similarities, as do their processes of financial management.

The legal foundation-Constitution and FMAP - generally governs the budgetary principles, the appropriations, the financial budgeting and reporting and the financial management at the operational level. It regulates the parliament (either at the federal or at the cantonal level), the executive branch and the various public administration units. It also defines the financial management abilities of these bodies.

Most of the legally binding budgetary principles are standard. For instance, the principle of legality demands that there be a legal base for all expenditures and revenues. Expenditures and revenues must be balanced, at least in the long run. The principles of efficiency and effectiveness should guide spending behavior and contribute to balancing the budget. The principle of urgency also helps to prioritize expenditures and guarantee project necessity and feasibility. Earmarking main taxes and pre-appropriating them for specific types of expenditures are in principle prohibited. The user-pays principle is relatively uncommon, though it is mentioned in the FMAP of several cantons. It postulates that, wherever possible, beneficiaries of public services must bear the costs of these services.

${ }^{2}$ Fiscal rule is also often referred to as budget constraint or financial rule. 
In general, a typical cantonal FMAP is fairly detailed regarding the regulation of appropriations (i.e., the regulation of credits called Kreditrecht or droit des credits). Apart from complying with the principle of legality, every expenditure item must be based on a credit appropriated by the Parliament. An FMAP usually typically specifies four kinds of appropriations: budgetary, supplementary, contingent and ancillary.

The budgetary appropriation (Budgetkredit, crédit budgétaire) is the most straightforward, since the budget formally approved by the Parliament for the next fiscal year (i.e., the beginning-of-the-year budget) is largely the sum of the budgetary appropriations requested by the executive branch. Once approved, the budgetary appropriation counts as an authorization to spend for the specific and corresponding purpose.

The supplementary appropriation (Nachtragskredit, crédit supplémentaire) is a further 'authorization to spend'. This type of credit is requested by the executive branch during the fiscal year when the existing budgetary appropriation proves insufficient. Both budgetary and supplementary appropriations are valid only for the fiscal year at hand. Should these appropriations not be spent by the end of the year, the executive branch is not authorized to later spend what remains.

The two remaining kinds of appropriations are meant for projects lasting more than a fiscal year and that typically entail capital expenditures for infrastructure such as school or hospital buildings. To commit itself to such projects, the council of the executive branch (hereafter the Executive Council) must be reasonably confident that once it requests funds from Parliament via a budget appropriation that Parliament will agree to appropriate the necessary amount. To obtain this assurance, the Executive Council submits a contingent appropriation (Verpflichtungskredit, crédit d'engagement) for parliamentary approval. The request may be submitted at any time during the year and, in principle, is outside of the usual procedure for drafting and adopting the budget. A contingent appropriation authorizes the Executive Council to make commitments to the various stakeholders in the corresponding project, but does not count as an authorization to spend. For that, the executive branch must ask Parliament to transform the contingent appropriation into a budgetary appropriation for the portion that corresponds to the work to be carried out during the coming fiscal year. In case the amount of a contingent appropriation is not enough to complete the project, the executive branch may request an ancillary appropriation (Zusatzkredit, crédit complémentaire), meaning a supplementary contingent appropriation. These four kinds of appropriations require majority approval by Parliament. 


\subsection{Financial Process and Main Actors}

The financial process may vary between cantons. Figure 14.1 shows the sequence of a typical process with its respective outcome documents: the mission statement, the financial plan, the contingent appropriations, the budget, the financial statements, the audit report and the financial statistics. The fiscal year in question is designated as year $t$, and Fig. 14.1 shows when each step takes place relative to it. The Swiss fiscal year is the same as the calendar year, running from January 1 to December 31 .

Figure 14.1 underscores the decision-making power of the different participating bodies: the Executive Council, the Parliament and, in some cases, the citizens. The process may appear to be like that in other countries, but there are Swiss particularities, including the instruments of direct democracy, the preeminence of legislative over the executive branch and the fact that citizens directly elect the members of Executive Councils (Regierungsrat, Conseil d'Etat). This last characteristic contrasts with other countries in which executive members are not elected but appointed by a prime minister or president. In Swiss cantons, the member of the executive responsible for financial management (the finance minister) and other members responsible for thematic issues like education or health (the spending ministers) have additional incentives to play their typical roles in the financial process if they intend to run for re-election and want to present a positive record of their accomplishments. This creates checks and balances between the 'spending ministers' on the one side and the finance minister on the other side.

\subsubsection{Mission Statement and Financial Plan}

The financial process begins before the debate about allocating financial resources commences. In fact, the FMAP requires a newly elected Executive Council to immediately draw up a joint mission statement for Parliament covering the four- to five-year electoral term (if the executive has a longer-term vision, this time horizon sometimes can be extended). To ensure that the mission statement remains specific, the departments (the cantonal equivalent of national-level ministries) are required to design and cost out the projects which will fulfill this vision of the executive. These projects are then collected and subsumed within a multi-year financial plan (Finanzplan; plan financier) accompanying the mission statement. 


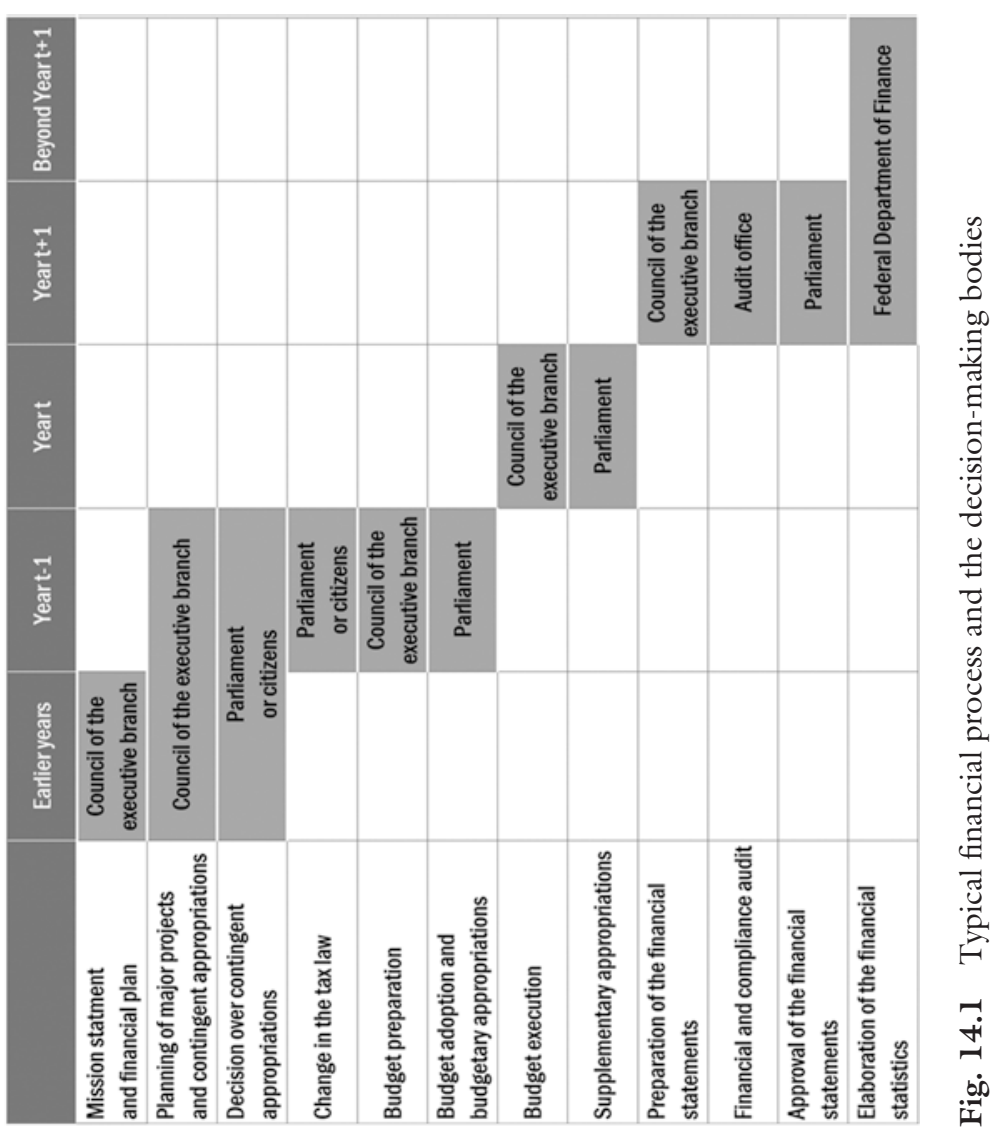




\subsubsection{Planning of Major Projects and Contingent Appropriation Requests}

Careful planning is necessary if a mission statement, or existing legislation, calls for implementing major projects, because the FMAP lays out special features before any spending can occur. As already mentioned, a contingent appropriation is necessary for multi-year projects. Additionally, should the amount requested exceed a predetermined amount (see below), the FMAP requires that a referendum be held on the contingent appropriation which has been approved by parliament.

To illustrate this process, consider a department with a project that requires a contingent appropriation. The department must prepare a report justifying the project and planning for its finances (expected capital expenditure and receipt and recurring expenses and revenues). The report is submitted to other departments which are potentially affected, inviting them to express their views. As most projects have financial consequences, the department of finance (DoF) also offers its comments. In its report, the DoF evaluates whether the project meets the budgetary principles (efficiently, effectively, etc.). Next, the Executive Council considers the comments and debates about the project. Provided the expenditure level does not exceed its financial mandate, the Executive Council decides, definitively, whether to accept it or not. Otherwise it must pass the request on to the Parliament.

\subsubsection{Decision over Contingent Appropriation Requests}

Once the executive branch passes the request to Parliament, the relevant parliamentary commissions (financial or thematic) analyze the project and forward their opinion to the plenum. Depending on the amount involved, Parliament's decision is enforceable or may be challenged by popular referendum. Once the project and the corresponding contingent appropriation are accepted, be it by the Executive Council, the parliament or the citizens after a referendum, it must then be translated into annual installments, in the form of budgetary appropriations in the next budget and beyond that in the annual forecasts of the multi-year financial plan.

\subsubsection{Budget Preparation}

In Switzerland, the budget reflects the existing legal foundations, including the tax provisions. Due to time constraints associated with launching a referendum against a law, the possibilities of adapting laws when preparing 
the budget are limited. In countries without this right, the government is freer to amend its laws, including tax laws, when creating its budget. In Switzerland, the decisions surrounding public policies and their execution therefore come into play well before the creation of the budget.

That being said, the annual budget (for year $t$ ) is prepared simultaneously with updating the financial plan for the following years. The usual time horizon for the plan is three years $(t+1$ to $t+3)$. Accordingly, the previous plan is considered when elaborating a budget and updating the financial plan. However, this is not binding, and an Executive Council will issue fresh guidelines to the various departments which are based on the DoF forecasts of expected revenues and projected tax revenue.

The finance ministers, as heads of the respective DoFs, are usually very cautious in their tax revenue forecasts, often underestimating them in an attempt to rein in the appetite for budgetary appropriations before the fact (Chatagny and Soguel 2012). Once the DoF receives the various departmental claims for budgetary appropriations and consolidates them, the total usually exceeds the guidelines or the expected revenues, or fails to meet the target imposed by a canton's FMAP fiscal rule (see below). It typically takes several rounds of negotiations between the DoF and the spending departments (typically education, social welfare or health) to finalize the budget. The Executive Council intervenes when administrative departments cannot agree. The budget is prepared according to the standards for presentation provided in the FMAP, standards which also apply to presenting the financial statements at year's end.

The above depiction of executive-level budget preparation suggests that this preparation is a bottom-up and incremental process. It is certainly still so in many cantons where the budgetary appropriation claims for year $t$ are based on budgetary appropriations approved by Parliament for the previous year $(t-1)$. Only large efficiency distortions, the need to finance new projects, or fiscal stress might force the government to systematically review existing programs. According to Aschwanden and Gerny (2013), this happened in 2013 when 16 cantons experienced unusual difficulties in balancing their budgets and had to adjust them.

With the onset of the New Public Management, performance-based budgeting has been implemented in some cantons. In this case, Parliament no longer governs the executive exclusively in an input-oriented manner but also specifies the expected qualitative or quantitative characteristics of the public service to be provided. Along with these specifications come the corresponding budgetary appropriations. This makes the budget process 
more output-oriented. For instance, in the canton of Aargau, Parliament sets the health department goals for school-based immunization.

In line with strengthening the fiscal rules, many cantons have also adopted a more top-down budgeting process. Fiscal rules straitjacket the government's budget and it becomes legally virtually impossible to run deficits. Therefore, the forecasts of expected revenues made by a DoF at the outset of the process are more binding than when the fiscal rules were softer. To make sure the fiscal rule requirement is fulfilled, the Executive Council, sometimes with the approval of the Parliament's standing committee on finance, undertakes the initial budgetary appropriation and allocates the forecasted revenues between the departments. This approach enables a better match between the council's mission statement and the budget. Every department then is required to allocate the granted appropriation-but not more- to the various tasks it must carry out.

\subsubsection{Budget Adoption}

Most cantonal parliaments must only take note of the updated financial plan referred to it by the executive branch in early autumn. Parliamentary budget debate thus focuses on the budget for the next fiscal year, with preliminary discussions taking place in several parliamentary commissions. The financial commission usually takes a defensive position, trying to maintain the balance proposed by the Executive Council, while each thematic commission tries to expand its own public services by advocating for more expenditures, whether for education, health or culture. Eventually, the budget is accepted by Parliament in December.

In principle, Parliament has the final say in the budget, giving it more power than the Executive Council. However, the tight schedule prevents Parliament from initiating fundamental changes once the budget has been submitted to it (Pfäfli 2011), which means power actually resides in the Executive Council and the public administration. Nevertheless, when a tax law change is proposed while the budget is in preparation, the proposal can be subject either to a mandatory or optional referendum, giving the final say to the citizens.

For instance, in late 2016, voters in the canton of Lucerne rejected the tax rate increase proposed by Parliament and thus rejected the proposed 2017 budget. Consequently, the government had to start the 2017 fiscal year without a valid budget until the Parliament agreed over the necessary spending cuts that enabled compliance with the fiscal rule 
without increasing the tax rate. The agreement was reached in mid-September 2017 only. In the meantime, the executive branch had to limit itself to necessary spending related to contracts already signed (von Däniken 2017).

The threat of a referendum gives both the Executive Council and the administration incentives to initially propose an acceptable budget. However, a power gap still exists between the government and the citizens because the latter by and large face a tie-in sale as they cannot decide upon individual budgetary appropriations. Yet two mechanisms are available which allow citizens to directly influence the budget allocation: (1) using a financial referendum to fight a contingent appropriation proposal or (2) launching a popular initiative (petition) requiring a change in legislation that would then increase or decrease expenditures (see below).

\subsubsection{Budget Execution and Supplementary Appropriations}

The executive branch executes the budget once it has been approved by Parliament. The executive branch applies the budget. Indeed, the budget appropriations give the executive branch the right to spend monies, up to the appropriated limit and for the prescribed purposes, between 1 January and 31 December of Year $t$.

Budget implementation usually does not go as planned. The cost of some inputs or the demand for certain public services may increase, and so initial budgetary appropriations may not suffice. The Executive Council has some leeway in reallocating initial appropriations, but the need may be greater than what has been already appropriated. In that case, the executive branch submits a request to Parliament for a supplementary appropriation.

\subsubsection{Preparation of the Financial Statements}

The fiscal year-end period rings in the preparation of the annual financial statements. The DoF prepares them under the accrual basis of accounting according to the FMAP. This involves the faithful representation of the effects of transactions, as well as other events and conditions, in accordance with the definitions and recognition criteria for assets, liabilities, revenue and expenses. It also involves some book entries that satisfy secondary interests rather than present the financial situation as it is. Insofar 
as these entries are within the limits of the FMAP, the literature calls them creative accounting or political finessing techniques (Clémenceau and Soguel 2018) ${ }^{3}$.

Indeed, the finance ministers have incentives to exploit the opportunities for political finessing provided by the FMAP. First, techniques can directly help fulfill the fiscal rule, especially if the rule is stringent. Second, an excessive deficit, but also a large surplus, may place the finance minister in an awkward position. In case of a deficit, citizens may judge that the minister has lost control of the public finances. In case of a surplus, they may feel they are paying too much in tax and demand either greater public spending or a reduction of the tax burden (e.g., using a popular initiative). If these claims are successful, the long-term fiscal balance is at risk, especially if the surplus was triggered by a favorable business cycle. The prospect endangers compliance with existing fiscal rule as well as the finance minister's re-election chances (Clémenceau and Soguel 2017).

\subsubsection{Financial and Compliance Audit of the Financial Statements}

The FMAP requires the auditing of the financial statements and sets the reference terms for the auditor. It explicitly requires a financial and compliance audit, in order to investigate the legality of expenditures, the proper recording of receipts and the correct operation of receipts and expenditures controls. The auditor must certify the absence of fraud and whether reports follow the law. It is worth noting that in most cantons, this does not require the auditor to certify whether the reports actually provide a true and fair presentation. That paradox is worth mentioning, since the FMAP often allows the aforementioned political finessing. The auditor's report is sent to Parliament together with the financial statements.

Each canton has an audit office (Finanzkontrolle; Contrôle des finances), governed by a cantonal law that is usually distinct from the FMAP. Depending on the canton, the head of the audit office is appointed by the Executive Council or by Parliament. The audit office is usually administra-

\footnotetext{
${ }^{3}$ The most common possibility—but not the obligation — offered by FMAPs for political finessing is to discretionarily inflate operating expenses with a book entry called 'additional depreciation charges'. The aim is to accrually and artificially lower the reported surplus. This book entry must not be confused with the true depreciation charges representing actual wear and tear or the obsolescence of assets.
} 
tively attached to the finance minister. However, it is only in the law's debt and is therefore functionally independent when it acts as external auditor of the financial statements for the benefit of Parliament. Aside from its function as external auditor, it supervises the entire government during the fiscal year with respect to the principles noted above (legality, urgency, economy, etc.). In this capacity, it acts as an internal auditor for the benefit of the Executive Council, in a manner like that found in the private sector ${ }^{4}$.

\subsubsection{Approval of the Financial Statements}

Once the financial statements are audited, the Executive Council submits them to the Parliament for approval, which is a mere formality.

\subsubsection{Elaboration of the Financial Statistics}

The last step of the financial process consists in making the information contained in the financial statements of the 26 cantons-but also of the municipalities and of the central government-comparable and available for further analysis. This takes place in the years that follow the presentation of the financial statements by the various governments at all three levels.

The presentation of the financial statements is supposed to be harmonized between all these entities, but in reality, this is far from being the case. The central government's DoF has the unenviable task of overseeing financial statistics for the entire country, and along with the variation in what is reported. Notably, the scope of the financial statements must be harmonized, since some cantons, for instance, include hospitals in their accounts while others do not; the same prevails for universities or for job centers. Dealing with all these difficulties, ensuring that financial statistics satisfy quality requirements and comply with international guidelines (IMF Statistics Department 2014) thus takes a lot of effort and time. This is the price to be paid in a system as decentralized as the Swiss one.

\footnotetext{
${ }^{4}$ Anachronistically, two cantons (Geneva and Vaud) have decided to install a court of auditors (Rechnungshof; Cour des comptes) in addition to the audit office they already have. The idea was to have a more independent authority to supervise the government's work. The members of this court are elected by direct universal suffrage in Geneva and by Parliament in Vaud. Strangely enough, in Vaud, the court of auditor's main task is performance auditing rather than compliance auditing.
} 


\subsection{Two Specific Institutions Constraining the Public Finances}

The economic literature gives various reasons for the existence of deficits or surpluses (Krishnakumar et al. 2010). When it comes to Switzerland, it is worth focusing on two institutions which are particularly significant for the management of the different tiers of Swiss government: the fiscal rules and the financial referendum.

Switzerland experienced an economic depression in the 1990s, with a resulting increase in its sovereign debt attributed to two asymmetries. First, governments behave asymmetrically by tolerating or engaging in deficit spending when the economy is in recession without securing surpluses when the economy is booming. The second asymmetry is that decision-making competency for expenditures is not granted at the same institutional level as it is for receipts. Parliament can often decide autonomously to spend, but a tax increase proposal must be put to a popular referendum (Lienhard and Marti Locher 2015).

\subsubsection{Fiscal Rules}

Fiscal rules and financial referenda have long been implemented to mitigate both asymmetries: The canton of St. Gallen implemented a socalled debt brake (debt containment rule) already in 1929. It was (anecdotally) reported that its debt level began decreasing two years after the debt brake was introduced, whereas it continued to rise in the other cantons. By now, all cantons but one (the small half-canton of Appenzell Innerrhoden) have introduced a fiscal rule, but the design and stringency of the fiscal rule varies widely. Some cantons anchored it in their constitution and others only in their FMAP, where it is easier to modify. The rule sometimes applies to the budget (beginning-of-theyear), sometimes to the annual account (end-of-the-year) and sometimes to both. In general, rules require balancing the budget, but this may apply to all transactions or only those entered in the operating account (i.e., excluding capital expenditure and receipts). Sometimes, a time period by which a fiscal balance must be obtained is explicitly required, as well as a sanction mechanism in case of missed targets, for example, a compulsory tax increase (Yerly 2014). Empirical evidence shows that cantons with stricter rules have significantly lower budget deficits and debt (Feld and Kirchgässner 2008). 
As for the central government, $85 \%$ of Swiss voters supported the implementation of a debt brake. The mechanism is thus anchored in the Federal Constitution and has been applied since 2003. The rule requires balancing the budget over the course of a business cycle. To achieve that goal, expenditures are capped each year with a ceiling that depends on the annual receipts, adjusted for the economic situation. The adjustment is calculated using a cyclical factor-the ratio of potential gross domestic product (GDP) to actual GDP - with which the receipts are multiplied. When the economy is depressed and the output gap negative, the factor is greater than one. In this way, the ceiling for expenditures is higher than the actual receipts, allowing for a deficit. When the economy is booming and the output gap positive, the factor is less than one. The ceiling for expenditures is then lower than the actual receipts, requiring a surplus. In exceptional circumstances, a qualified majority in parliament can raise the expenditure ceiling. By considering the business cycle in a mechanical way, the federal fiscal rule offers the automatic stabilizers the room they need to function, and even offers the government some flexibility in taking counter-cyclical measures.

\subsubsection{Financial Referendum and the Right of Initiative}

The financial referendum is an instrument a majority of cantons have adopted; it can be optional or mandatory. It applies if a one-time or recurring expenditure exceeds a defined threshold. The threshold varies significantly among the cantons: between 250,000 and 25 million CHF for non-recurring expenditures and from 50,000 to 400,000 CHF for recurring expenditures. When the possibility of an optional referendum exists, meaning that the population must petition to have an expenditure put to a popular vote, the required number of petitioners (i.e., the number of signatures to collect) also varies from 100 to 10,000 citizens, depending on the canton. Empirical evidence shows that where mandatory financial referenda exist, expenditures are significantly lower (Funk and Gathmann 2011). For instance, in the alpine canton of Graubünden, the instrument was successfully used in 2017 to combat the Executive Council's request for a contingent appropriation to organize the 2022 Olympic Winter Games.

The introduction of a financial referendum at the central level has been discussed for some time, but such proposals have never been able to appeal to a majority in Parliament. Opponents fear possible delays in the political 
process. They also think it is useless, since a large portion of central government expenditures are annual transfer payments to other public entities, notably the cantons.

Swiss citizens also can make use of their right to launch popular initiatives to influence public finances; since government budgets as such are legally beyond the control of the referendum. A striking example was provided by the 'redistribution initiative' launched in 1997 by the Social Democratic party. It called for a popular vote on a proposal to amend the Federal Constitution and oblige the central government to cut military expenditures in half over ten years and invest one-third of the savings into international peace efforts. The initiative was rejected by $62 \%$ of the voters, although it was accepted in four French-speaking cantons.

\subsection{Conclusion}

The various Swiss financial management systems have some unique features, both due to the interplay of the instruments for direct democracy and with Parliament not being under the Executive Council's thumb. Considered together, these elements build systems of checks and balances that have led-particularly in the last two decades - to sound public budgets with relatively low debt levels.

Having said that, the system could be improved, for as in almost every country, Parliament is granted only a limited time to scrutinize proposed budgets. The result is to have the approved budget that strongly resembles the Executive Council's proposed budget. Additionally, since the finance minister acts within the Executive Council as one among equals, there is an inherent risk of finding all the 'spending ministers' arrayed against the sole 'budget minister'. Financial concerns become demoted through this situation, though thus far, the conservative stance of finance ministers has helped control this risk.

The finance minister sometimes also has recourse to political finessing, for instance, by underestimating tax receivables when preparing the budget or by artificially inflating some accrued expenses. This has proven useful for guaranteeing sound public financing - though it is detrimental to the fair view one expects from a governments' financial statements. Accurately reporting the financial situation will not expose Swiss governments unduly, especially if the instruments of direct democracy are in place and working. In that respect, those cantons that do not have a financial referendum, or that have eliminated this possibility, might want 
to reconsider. Cantons where the fiscal rule is not stringent enough should reinforce this constraint, as long as it is adjusted to the business cycle in the manner of the federal debt break.

\section{REFERENCES}

Aschwanden, E., \& Gerny, D. (2013, August 15). Kantone sparen über 1 Milliarde. Nene Zürcher Zeitung, p. 13.

Chatagny, F., \& Soguel, N. (2012). The effect of tax revenue budgeting errors on fiscal balance: Evidence from the Swiss cantons. International Tax and Public Finance, 19(3), 319-337.

Clémenceau, M., \& Soguel, N. (2017). Does personal background influence a finance minister to cook the books? An investigation of creative accounting in Swiss cantons. Applied Economics, 49(10), 941-953.

Clémenceau, M., \& Soguel, N. (2018). How does depreciations management affect subsequent fiscal performance? The case of the Swiss cantons. Swiss Journal of Economics and Statistics, 154(7), 1-15.

Feld, L., \& Kirchgässner, G. (2008). On the effectiveness of debt brakes: The Swiss experience. In R. Neck \& J.-E. Sturm (Eds.), Sustainability of public debt (pp. 223-255). Cambridge: MIT Press.

Funk, P., \& Gathmann, C. (2011). Does direct democracy reduce the size of government? New evidence from historical data 1890-2000. The Economic Journal, 121(557), 1252-1280.

IMF (International Monetary Fund) Statistics Department. (2014). Government finance statistics manual. Washington, DC: International Monetary Fund.

Krishnakumar, J., Martin, M.-J., \& Soguel, N. (2010). Explaining fiscal balances with a simultaneous equation model of revenue and expenditure: A case study of Swiss cantons using panel data. Public Budgeting and Finance, 30(2), 69-94.

Lienhard, A., \& Marti Locher, F. (2015). Art. 126. In B. Waldmann, E. M. Belser, \& A. Epiney (Eds.), Bundesverfassung, Basler Kommentar (pp. 2025-2038). Basel: Helbing Lichtenhahn Verlag.

Pfäffli, S. (2011). Budgetierung im öffentlichen Sektor: ein Handbuch für Studium und Praxis aus finanzwissenschaftlicher Sicht. Berne: Haupt Verlag AG.

Von Däniken, A. (2017, May 26). Budget: Es geht um alles oder nichts. Luzerner Zeitung. Retrieved from http://www.luzernerzeitung.ch

Yerly, N. (2014). Les règles budgétaires entre souplesse et rigidité: la situation des cantons suisses. La Vie économique, 6, 38-40. 
Open Access This chapter is licensed under the terms of the Creative Commons Attribution 4.0 International License (http://creativecommons.org/licenses/ by $/ 4.0 /$ ), which permits use, sharing, adaptation, distribution and reproduction in any medium or format, as long as you give appropriate credit to the original author(s) and the source, provide a link to the Creative Commons license and indicate if changes were made.

The images or other third party material in this chapter are included in the chapter's Creative Commons license, unless indicated otherwise in a credit line to the material. If material is not included in the chapter's Creative Commons license and your intended use is not permitted by statutory regulation or exceeds the permitted use, you will need to obtain permission directly from the copyright holder.

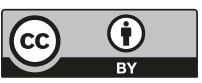

